\title{
EVALUATION OF SELECTED RISK FACTORS FOR CARDIOVASCULAR DISEASES AND DIABETES AS A BACKGROUND FOR THE PREVENTION PROGRAM IN OCCUPATIONAL HEALTHCARE
}

\section{AGNIESZKA LIPIŃSKA-OJRZANOWSKA ${ }^{1}$, JOLANTA WALUSIAK-SKORUPA ${ }^{1}$, MARCIN OJRZANOWSKI ${ }^{2}$, ANDRZEJ MARCINKIEWICZ ${ }^{1}$, MICHAŁ PLEWKA ${ }^{2}$, and MARTA WISZNIEWSKA ${ }^{1}$}

\author{
${ }^{1}$ Nofer Institute of Occupational Medicine, Łódź, Poland \\ Department of Occupational Diseases and Environmental Health \\ ${ }^{2}$ Medical University of Lodz, Łódź, Poland \\ Chair and Department of Cardiology
}

\begin{abstract}
Objectives: Cardiovascular and metabolic disorders constitute major health problems in the working populations in Europe. The aim of this project was to evaluate the health condition of workers employed in a Polish research and medical institution, and then to establish the necessary preventive actions by creating a modern model of occupational healthcare integrated with civilization disease (CivD) prevention. Material and Methods: Overall, 100 workers voluntarily participated in a health program for CivD prevention during mandatory prophylactic examinations. Data from these examinations was collected in a system of electronic documentation to enable the analysis of the workers' health condition and risk factors of CivDs. Results: Women accounted for $72 \%$ of the employees who voluntarily participated in the prevention program, and $80 \%$ of the subjects had university education. As regards the health condition, $27 \%$ of the patients had elevated systolic, and $23 \%$ diastolic, blood pressure, and $21 \%$ had an abnormal fasting glucose level. Stressful job was an important factor correlated with an excessive body mass index, diastolic blood pressure, as well as total and low-density lipoprotein cholesterol levels. Smoking, sedentary work and a lack of physical activity were significant factors for abdominal obesity. Generally, $94 \%$ of the program participants required some further interventions in lifestyle, diagnostics or treatment. Conclusions: Civilization disease prevention should focus on increasing physical activity both in leisure time and at the workplace as far as practicable. There is a need for implementing projects leading to occupational stress reduction and smoking cessation. Men as well as workers with vocational and elementary education need to be recruited for prevention programs dedicated to employees. Int J Occup Med Environ Health. 2021;34(3):403-13
\end{abstract}

Key words:

occupational medicine, health promotion at the workplace, occupational health system, risk factors of civilization diseases, Systemic Coronary Risk Evaluation, health of the working-age population

\footnotetext{
Funding: this study was supported by the Nofer Institute of Occupational Medicine in Łódź (project No. 12.10 entitled "Prophylactic care of the workers employed in the Institute of Occupational Medicine in Lodz on the basis of the «Integrated system for development and implementation of infrastructure for protection of health of working population» as the element of the implementation of a programme," project manager: Dr. Agnieszka Lipińska-Ojrzanowska) and National Health Program (grant No. 6/4/2.1.2/NPZ/2016/312/1656 entitled "Initiatives taking in the point of prophylaxis occupational and work-related diseases, including military services and supporting health condition of working population").

Received: August 23, 2019. Accepted: October 27, 2020.

Corresponding author: Agnieszka Lipińska-Ojrzanowska, Nofer Institute of Occupational Medicine, Department of Occupational Diseases and Environmental Health, św. Teresy 8, 91-348 Łódź, Poland (e-mail: agnieszka.lipinska-ojrzanowska@imp.lodz.pl).
} 


\section{INTRODUCTION}

Despite some efficient results in cardiovascular diseases (CVDs), current treatment and decreasing addiction to tobacco products, CVDs together with cancer are still the leading causes of morbidity and mortality in many welldeveloped industrial countries [1]. Obesity and other metabolic disorders, which constitute risk factors for CVDs, are considered responsible for this drift [2,3]. Statistics Poland has estimated that CVDs cause almost $46 \%$ of all deaths [4].

Specific workplace conditions and nuisances may also increase health hazards. Both sedentary and hard physical work, as well as working night shifts or having a stressful job, are favorable to metabolic syndrome and CVD development, and especially to their complications such as type 2 diabetes, coronary heart failure and stroke [5-7]. An effective prevention of civilization diseases (CivDs) demands the implementation of actions promoting a "healthy lifestyle" and reducing the risk factors for CivDs in the whole population and under an individual approach [1,8,9]. The Polish legislation system of mandatory prophylactic examinations of workers [10] provides a great opportunity to run an effective prevention of CivDs in people who do not use healthcare services on everyday basis. The Systemic Coronary Risk Evaluation (SCORE) is a scale that plays an essential role in the prevention of CVDs in people in a generally good health condition without any previous diagnosis of CVDs. Such patients do not visit their family doctor, so their workplace gives the most obvious opportunity to take preventive actions. The European Society of Cardiology (ESC) and the Polish Cardiac Society recommend estimating the systemic coronary risk in every patient aged $>40$ years by means of the SCORE chart [1,11], and in the Polish population by means of its modified version, POL-SCORE, for high-risk populations [12].

The aim of this project was to evaluate selected risk factors for CVDs and diabetes among employees during mandatory prophylactic examinations with the enhancement of obligatory regulations, and to establish the necessary preventive actions.

\section{MATERIAL AND METHODS}

In May 2016-May 2018, 100 workers of a research and medical institution who underwent mandatory prophylactic examinations, with the scope and frequency determined by the Polish legislation, due to harmful occupational hazards [10], voluntarily participated in an additional health program for the prevention of selected CivDs. The office workers group included clerks, editors, computer engineers and scientists (sociologists, psychologists, masters of public health science); the medical staff group comprised physicians, nurses and laboratory workers; and the physical workers group was formed by mechanics, cleaners and repairmen.

The medical interview focused on any present and past health disorders, the smoking habit, daily physical activity, and a family history of diabetes and CVDs. The occupational medicine physician took a body weight and height of each employee, determined the body mass index (BMI), and measured the abdominal circumference, blood pressure and pulse. All of the participants underwent electrocardiography (ECG) and the following laboratory tests: fasting blood glucose level (FGL) and the lipid serum profile. Finally, the physician analyzed the results and provided an individual assessment of the risk factors for the occurrence of selected CivDs, or for developing/aggravating the course of CVDs or diabetes. In the workers aged $>40$ years, the risk of death in the next 10 years due to CVDs was also estimated by means of the POL-SCORE chart [12]. Each participant was given information about their respective health risk and individual recommendations related to reducing body weight trough daily physical activity [1,13-19] and diet change [20-22], the possible ways of quitting the smoking habit [1,23-26], the need to start or modify pharmacotherapy, etc. The workers also received recommendations to obtain self-educating materials from selected websites [27,28]. 
All the data from medical check-ups was collected in a system of electronic documentation called "The Integrated system of drawing up and implementing the computer infrastructure in the health care working (POIG)." An electronic form of the integrated computer system provides an access to record-keeping data analyzed for assessing the workers' health condition, risk factors of CiVDs during the following periodical medical check-ups.

The statistical analyses were performed by means of Statistica 8.0. Qualitative data was compared using $2 \times 2$ contingency tables with Fisher's test, and the clinical relevance of selected parameters for appropriate disorders was established by single-factor repeated measures ANOVA. A 2-tailed p-value of $<0.05$ was considered as significant. Median variances were analyzed using the Kruskal-Wallis modification of the ANOVA test.

\section{RESULTS}

The characteristics of the study group was presented in Table 1 . The majority of the volunteers were women (72\%) and $80 \%$ of the subjects had university education.

Sedentary work was reported as the most common occupational nuisance (85\%), followed by a high level of stress in the workers aged 30-59 years, but not in the younger ( $<30$ years) and older ( $\geq 60$ years) employees. As many as $50 \%$ of the subjects denied any regular physical activity, and a sedentary lifestyle was observed the most frequently among the employees aged 30-59 years, while the younger and older ones were more active.

Less than a half of the examined workers had an appropriate BMI and waist circumference, with the exception of employees aged $<30$ years. The median value of BMI amounted to $27 \mathrm{~kg} / \mathrm{m}^{2}$ in women and $23 \mathrm{~kg} / \mathrm{m}^{2}$ in men, and the female gender was an important factor for excessive BMI (Table 2). The people who had ever smoked had a significantly lower BMI than non-smokers (the median value of BMI was 23 vs. $27 \mathrm{~kg} / \mathrm{m}^{2}$ ) (Table 3). On the other hand, ever smoking and active smoking, as well as sedentary work and a lack of physical activity, were significant factors for abdominal obesity (Table 2). In general, active smokers had a lower median value of FGL and a higher value of triglycerides (TG) than the people who had never smoked or were past smokers (Table 3). The most significant difference was seen between the median value of BMI in physical workers $\left(30.2 \mathrm{~kg} / \mathrm{m}^{2}\right)$ in comparison with other employees $\left(24.3 \mathrm{~kg} / \mathrm{m}^{2}\right)$. The workers who reported having a stressful job, in relation to those who did not indicate stress as an occupational nuisance, had a visible difference in the median values of BMI ( $\left.27 \mathrm{vs.} 23 \mathrm{~kg} / \mathrm{m}^{2}\right)$. Stress at work was also an important factor for increased low-density lipoprotein cholesterol (LDL-C) and diastolic blood pressure (DBP) (Table 2).

During the visit, $27 \%$ of the patients had elevated systolic blood pressure (SBP), 23\% had elevated DBP, and 21\% had abnormal FGL (Table 1). The male gender was an important factor for an increased level of FGL, as well as for an elevated level of TG, SBP and DBP (Table 2). Hypercholesterolemia, defined as the total cholesterol (TC) level in venous blood of $\geq 190 \mathrm{mg} / \mathrm{dl}$, was found in $42 \%$, and LDL-C of $\geq 115 \mathrm{mg} / \mathrm{dl}$ in $36 \%$, of the subjects, and both of these parameters were elevated in $48 \%$ of them. In $12 \%$ of the employees with elevated TC, LDL-C was in the normal range, a subtly elevated LDL-C with concentrations of approx. $119 \mathrm{mg} / \mathrm{dl}, 119 \mathrm{mg} / \mathrm{dl}$ and $120 \mathrm{mg} / \mathrm{dl}$ was found in only $3 \%$ of the workers with $\mathrm{TC}$ in the normal range.

In $10 \%$ of the subjects (all of them aged $>40$ years), routinely conducted ECG revealed abnormalities: supraventricular arrhythmia de novo (3\%), left axis deviation (6\%) co-existing with bundle branch block in 3 cases, and ischemic changes in 1 person. All of these employees were referred to a cardiologist.

Generally, almost $94 \%$ of the program participants required some interventions, such as direct advice regarding lifestyle modifications and/or additional specialist consultations (e.g., with a cardiologist, a nutritionist, or an endocrinologist). 
Table 1. Characteristics of the study group of workers of a research and medical institution in Poland, who voluntarily participated in an additional health program for the prevention of selected civilization diseases during mandatory prophylactic examinations, May 2016-May 2018

\begin{tabular}{|c|c|c|c|c|c|c|}
\hline \multirow[t]{2}{*}{ Variable } & \multicolumn{6}{|c|}{$\begin{array}{c}\text { Participants } \\
(\mathrm{N}=100) \\
{[\mathrm{n}(\%)]}\end{array}$} \\
\hline & $\begin{array}{l}<30 \text { years } \\
(\mathrm{N}=11)\end{array}$ & $\begin{array}{c}30-39 \text { years } \\
(\mathrm{N}=19)\end{array}$ & $\begin{array}{c}40-49 \text { years } \\
(\mathrm{N}=23)\end{array}$ & $\begin{array}{c}50-59 \text { years } \\
(\mathrm{N}=34)\end{array}$ & $\begin{array}{c}60-69 \text { years } \\
(\mathrm{N}=13)\end{array}$ & total \\
\hline \multicolumn{7}{|l|}{ Gender } \\
\hline female & $10(91)$ & $13(68)$ & $19(83)$ & $25(74)$ & $5(38)$ & 72 \\
\hline male & $1(9)$ & $6(32)$ & $4(17)$ & $9(26)$ & $8(62)$ & 28 \\
\hline \multicolumn{7}{|l|}{ Education } \\
\hline vocational/elementary & 0 & 0 & 0 & $1(4)$ & $1(7.5)$ & 2 \\
\hline secondary & $1(9)$ & 0 & $5(22)$ & $11(32)$ & $1(7.5)$ & 18 \\
\hline university & $10(91)$ & $19(100)$ & $18(78)$ & $22(64)$ & $11(85)$ & 80 \\
\hline \multicolumn{7}{|l|}{ Occupation } \\
\hline medical staff ${ }^{a}$ & $4(36)$ & $9(47)$ & $9(39)$ & $13(38)$ & $2(15)$ & 37 \\
\hline office workers ${ }^{\mathrm{b}}$ & $7(64)$ & $10(53)$ & $11(48)$ & $15(44)$ & $8(62)$ & 51 \\
\hline physical workers $^{\mathrm{c}}$ & 0 & 0 & $3(13)$ & $6(18)$ & $3(23)$ & 12 \\
\hline \multicolumn{7}{|l|}{ Workstand nuisances } \\
\hline sedentary work & $9(82)$ & $18(95)$ & $21(91)$ & $27(79)$ & $10(77)$ & 85 \\
\hline shift work & $3(27)$ & $5(26)$ & $5(22)$ & $7(21)$ & $1(7.7)$ & 21 \\
\hline stress & $3(27)$ & $15(79)$ & $13(57)$ & $20(59)$ & $3(23)$ & 54 \\
\hline hard physical work & 0 & $3(16)$ & $5(22)$ & $7(21)$ & $3(23)$ & 18 \\
\hline Smoking habit & $1(9)$ & $4(21)$ & $4(17)$ & $15(44)$ & $7(54)$ & 33 \\
\hline actual & 0 & $1(5)$ & $2(8.5)$ & $7(21)$ & $3(23)$ & 13 \\
\hline past & $1(9)$ & $3(16)$ & $2(8.5)$ & $8(23)$ & $4(31)$ & 18 \\
\hline Family history of CivDs & $2(18)$ & $3(16)$ & $7(30)$ & $13(38)$ & $3(23)$ & 28 \\
\hline \multicolumn{7}{|l|}{ Daily physical activity } \\
\hline none & $2(18)$ & $10(53)$ & $12(52)$ & $22(65)$ & $4(31)$ & 50 \\
\hline 1-3 times/week & $2(18)$ & $5(26)$ & $8(35)$ & $7(21)$ & $5(38)$ & 27 \\
\hline$>3$ times/week & $7(64)$ & $4(21)$ & $3(13)$ & $5(15)$ & $4(31)$ & 23 \\
\hline \multicolumn{7}{|l|}{ BMI } \\
\hline$<18.5 \mathrm{~kg} / \mathrm{m}^{2}$ & $2(18)$ & $1(5)$ & 0 & 0 & 0 & 3 \\
\hline $18.5-24.99 \mathrm{~kg} / \mathrm{m}^{2}$ & $7(64)$ & $7(37)$ & $11(48)$ & $15(44)$ & $3(23)$ & 43 \\
\hline $25-29.99 \mathrm{~kg} / \mathrm{m}^{2}$ & $2(18)$ & $8(42)$ & $9(29)$ & $7(21)$ & $4(31)$ & 30 \\
\hline$\geq 30 \mathrm{~kg} / \mathrm{m}^{2}$ & 0 & $3(16)$ & $3(13)$ & $12(35)$ & $6(46)$ & 24 \\
\hline \multicolumn{7}{|l|}{ Waist circumference } \\
\hline females $<80 \mathrm{~cm}$ and males $<94 \mathrm{~cm}$ & $7(64)$ & $8(42)$ & $10(43)$ & $16(47)$ & $3(23)$ & 44 \\
\hline females $80-87.99 \mathrm{~cm}$ and males $<94-101.99 \mathrm{~cm}$ & $3(27)$ & $4(21)$ & $12(52)$ & $2(6)$ & $3(23)$ & 24 \\
\hline females $\geq 88 \mathrm{~cm}$ and males $\geq 102 \mathrm{~cm}$ & $1(9)$ & $7(37)$ & $1(4)$ & $16(47)$ & $7(54)$ & 32 \\
\hline
\end{tabular}


Table 1. Characteristics of the study group of workers of a research and medical institution in Poland, who voluntarily participated in an additional health program for the prevention of selected civilization diseases during mandatory prophylactic examinations, May 2016-May 2018 - cont.

\begin{tabular}{|c|c|c|c|c|c|c|}
\hline \multirow[t]{2}{*}{ Variable } & \multicolumn{6}{|c|}{$\begin{array}{c}\text { Participants } \\
(\mathrm{N}=100) \\
{[\mathrm{n}(\%)]}\end{array}$} \\
\hline & $\begin{array}{l}<30 \text { years } \\
(\mathrm{N}=11)\end{array}$ & $\begin{array}{c}30-39 \text { years } \\
(\mathrm{N}=19)\end{array}$ & $\begin{array}{l}40-49 \text { years } \\
(\mathrm{N}=23)\end{array}$ & $\begin{array}{c}50-59 \text { years } \\
(\mathrm{N}=34)\end{array}$ & $\begin{array}{c}60-69 \text { years } \\
(\mathrm{N}=13)\end{array}$ & total \\
\hline \multicolumn{7}{|l|}{ FGL } \\
\hline$\leq 99 \mathrm{mg} / \mathrm{dl}$ & $10(91)$ & $17(89.5)$ & $18(78)$ & $27(79.4)$ & $7(54)$ & 79 \\
\hline $100-125.99 \mathrm{mg} / \mathrm{dl}$ & $1(9)$ & $2(10.5)$ & $5(22)$ & $7(17.6)$ & $3(23)$ & 18 \\
\hline$\geq 126 \mathrm{mg} / \mathrm{dl}$ & 0 & 0 & 0 & 0 & $3(23)$ & 3 \\
\hline \multicolumn{7}{|l|}{ Dyslipidemia } \\
\hline $\mathrm{TC} \geq 190 \mathrm{mg} / \mathrm{dl}(\geq 5 \mathrm{mmol} / \mathrm{l})$ & $4(36)$ & $6(32)$ & $10(43.5)$ & $18(53)$ & $4(31)$ & 42 \\
\hline LDL-C $\geq 115$ mg/dl ( $\geq 3 \mathrm{mmol} / \mathrm{l})$ & $4(36)$ & $5(26)$ & $7(30)$ & $18(53)$ & $2(15)$ & 36 \\
\hline $\begin{array}{l}\text { HDL-C: females } \leq 40 \mathrm{mg} / \mathrm{dl}(\leq 1 \mathrm{mmol} / \mathrm{l}) \\
\text { and males } \leq 48 \mathrm{mg} / \mathrm{dl}(\leq 1.2 \mathrm{mmol} / \mathrm{l})\end{array}$ & 0 & $1(5)$ & $3(13)$ & $1(4)$ & $1(7.5)$ & 5 \\
\hline $\mathrm{TG} \geq 150 \mathrm{mg} / \mathrm{dl}(\geq 1.7 \mathrm{mmol} / \mathrm{l})$ & 0 & $1(5)$ & $4(17)$ & $5(15)$ & 0 & 10 \\
\hline mixed abnormalities ( $\uparrow \mathrm{TC}$ and $\uparrow \mathrm{TG}$ ) & 0 & 0 & $3(13)$ & $3(8.8)$ & 0 & 6 \\
\hline \multicolumn{7}{|l|}{ Arterial blood pressure level [mm Hg] } \\
\hline systolic ( $\geq 140 \mathrm{~mm} \mathrm{Hg})$ & $2(18)$ & $3(16)$ & $4(17)$ & 14 (41.2) & $4(31)$ & 27 \\
\hline diastolic ( $\geq 90 \mathrm{~mm} \mathrm{Hg}$ ) & $1(9)$ & $3(16)$ & $1(4.3)$ & $14(41.2)$ & $4(31)$ & 23 \\
\hline \multicolumn{7}{|l|}{ SCORE } \\
\hline$<1 \%$ & n.a. & n.a. & $9(29)$ & 0 & 0 & \\
\hline $1-4.99 \%$ & & & $12(52)$ & $14(41.2)$ & $2(15)$ & \\
\hline $5-9.99 \%$ & & & $1(4.3)$ & $4(11.8)$ & $1(7.5)$ & n.a. \\
\hline$\geq 10 \%$ & & & $1(4.3)$ & $16(47)$ & $11(85)$ & \\
\hline Abnormalities in ECG & 0 & 0 & $2(8.5)$ & $3(8.8)$ & $5(38)$ & 10 \\
\hline
\end{tabular}

CivDs - civilization diseases including cardiovascular disorders and diabetes; ECG - electrocardiography; FGL- fasting glucose level;

HDL-C - high-density lipoprotein cholesterol; LDL-C - low-density lipoprotein cholesterol; SCORE - Systemic Coronary Risk Evaluation;

$\mathrm{TC}$-total cholesterol in venous blood; TG - triglycerides.

n.a. - not applicable.

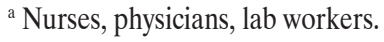

${ }^{\mathrm{b}}$ Clerks, computer engineers, editors, sociologists, psychologists, etc.

${ }^{\mathrm{c}}$ Cleaners, repairmen, mechanics.

\section{DISCUSSION}

In 2017 in Poland, >5.4 million mandatory examinations were carried out for the purpose provided for in the Labor Code $[10,29]$. This number included $>2.5$ million preliminary examinations, $>2.5$ million periodic examinations, and about 417000 control medical check-ups [4]. It was estimated that in 2017 about $99.5 \%$ of the mandatory prophylactic examinations provided a positive certification for work ability [4]; however, this study shows that even $94 \%$ of employees were in the need of some medical advice for 
Table 2. Clinical relevance of selected parameters and risk factors for health disorders among workers $(\mathrm{N}=100)$ in a research and medical institution in Poland, who voluntarily participated in an additional health program for the prevention of selected civilization diseases during mandatory prophylactic examinations, May 2016-May 2018

\begin{tabular}{|c|c|c|c|c|c|c|c|c|}
\hline \multirow[t]{2}{*}{ Variable } & \multirow[t]{2}{*}{ BMI } & \multirow{2}{*}{$\begin{array}{c}\text { Waist } \\
\text { circumference }\end{array}$} & \multirow[t]{2}{*}{ FGL } & \multicolumn{3}{|c|}{$\begin{array}{l}\text { Serum lipid profile } \\
{[\mathrm{mg} / \mathrm{dl}]}\end{array}$} & \multicolumn{2}{|c|}{$\begin{array}{l}\text { Blood pressure } \\
{[\mathrm{mm} \mathrm{Hg}]}\end{array}$} \\
\hline & & & & $\mathrm{TC}$ & LDL-C & TG & systolic & diastolic \\
\hline \multicolumn{9}{|l|}{ Gender } \\
\hline female & $\uparrow$ & & & & & & & \\
\hline male & & & $\uparrow$ & & & $\uparrow$ & $\uparrow$ & $\uparrow$ \\
\hline \multicolumn{9}{|l|}{ Smoking } \\
\hline ever & & $\uparrow$ & & & & & & \\
\hline active & & $\uparrow$ & & & & $\uparrow$ & $\uparrow$ & \\
\hline Family history of CivDs or diabetes & & & & & $\uparrow$ & & $\uparrow$ & \\
\hline \multicolumn{9}{|l|}{ Work } \\
\hline sedentary & & $\uparrow$ & & $\uparrow$ & $\uparrow$ & & & \\
\hline \multicolumn{9}{|l|}{ shift } \\
\hline hard physical & $\uparrow$ & & & & & & & \\
\hline Stress at work & & & & & $\uparrow$ & & & $\uparrow$ \\
\hline Lack of physical activity & & $\uparrow$ & & & & & & \\
\hline
\end{tabular}

Abbreviations as in Table 1.

$\uparrow$ Positive correlation of the parameter or the risk factor for the selected health disorder with a significance level at $\mathrm{p}$-value of $<0.05$.

improving their occupational safety and/or for modifying their previous lifestyle.

The results obtained for the group of voluntary participants in the prevention program cannot be viewed as representative for the entire population of Polish workers, because the available indicators for the last quarter of 2017 show a male dominance over the employed women, and of workers with primary vocational education over those with higher education [29]. On the other hand, this observation suggests that men and employees with vocational and elementary education in particular need to be recruited for prevention programs.

Sedentary work, reported as a major workstand nuisance by the employees involved in this project (85\%), combined with a lack of physical activity and stress, is an important non-dependent risk factor for CivD development. In 1953, Morris et al. [30] described a higher yearly incidence of ischemic heart disease and a higher percentage of deaths within 3 months since acute myocardial infarction, among public transport drivers in London in relation to ticket inspectors (approx. 2.7/1000 persons vs. 1.9/1000 persons, and $47 \%$ vs. $29 \%$ ). Japan researchers also indicated the negative impact of sedentary work on physical fitness and cholesterol profile in employees [31].

Stress, considered by the respondents as the second major nuisance at work, is responsible for the chronic stimulation of the neurovegetative system that plays an important role in the pathogenesis of CVDs and their complications such as stroke or myocardial infarction [32,33]. Moreover, some people cope with stress by addicting to tobacco products, which especially concerns women [34], or by abusing alcohol [35], which both promote CivD development. Furthermore, chronic stress, also at the workplace, has been proven to interfere with hypothalamic-pituitary-adrenal 


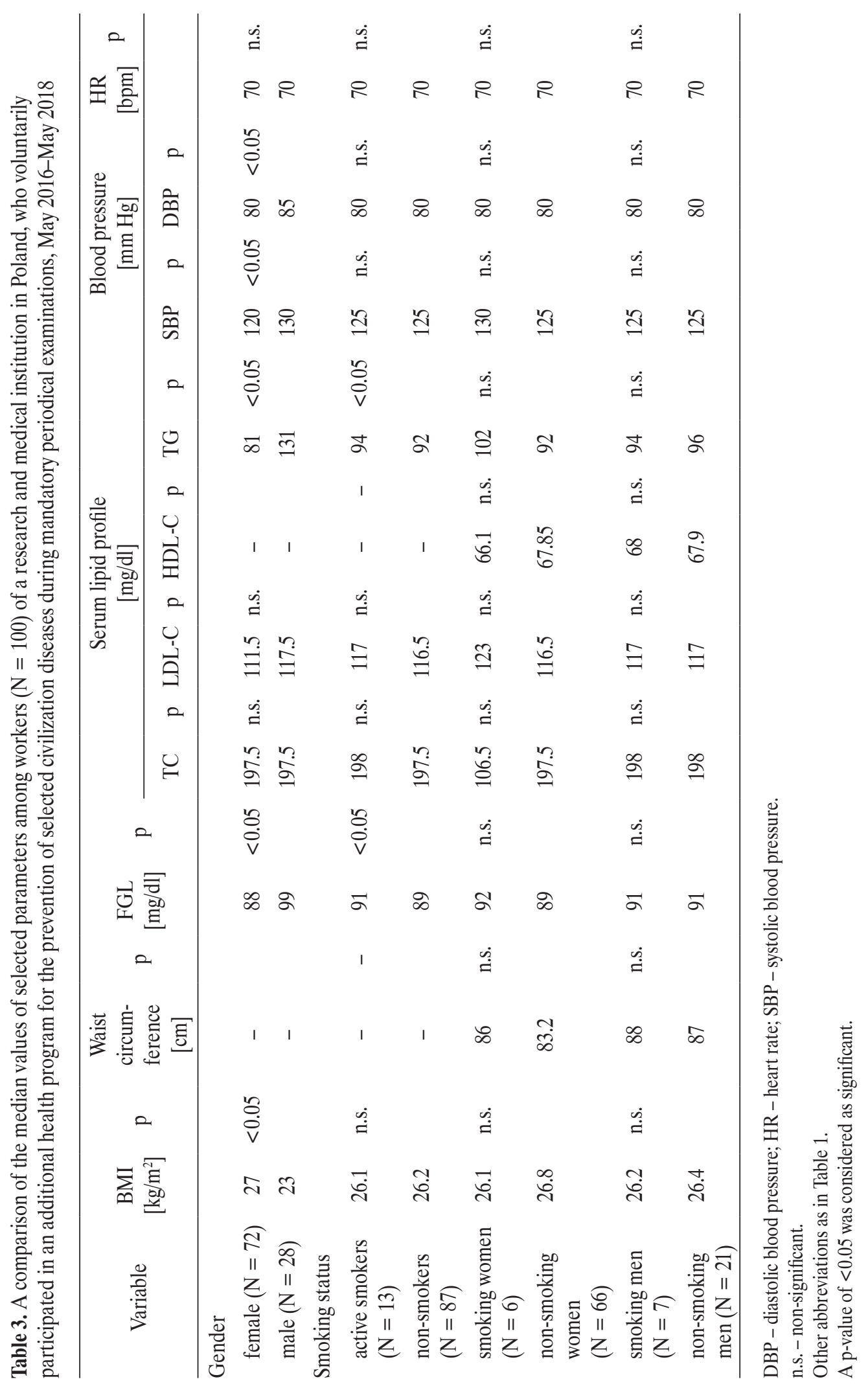


axis function [36], and a long-term increased cortisol level is responsible for the occurrence and progression of abdominal obesity. There is a real need for implementing programs supporting mental health and coping with stress designated for employees in the scope of health promotion at the workplace.

In this study, overweight afflicted workers aged 30 years (Table 1). Abnormal lipid profile was seen even in younger employees (Table 1). Disorders accrued with age and were more visible in the fourties and fifties, and they finally resulted in CivDs and their complications, eventually leading to starting up treatment. Therefore, the targets for the primary prevention of CivDs should be employees in their twenties and thirties, while secondary prevention must be directed to middle-aged workers. As previously reported, abdominal obesity was positively associated with the smoking status, whereas BMI was correlated negatively [37-40]. Nicotine, which is considered a metabolism booster, has been found to increase the cortisol blood concentration [41], which may lead to insulin resistance, followed by visceral adiposity and type 2 diabetes [42]. Occupational medicine should focus on quitting smoking through 2 approaches: implementing a smoking cessation policy at the workplace and supporting those employees who want to quit smoking during a prophylactic examination by giving them clear professional information.

The Polish Diabetes Association recommends testing the FGL in venous blood every 3 years among all people aged $>45$ years and in younger individuals with risk factors for diabetes (e.g., obesity, a family history of diabetes) $[43,44]$. The ESC and the European Atherosclerosis Society recommend performing screening tests for dyslipidemia among men aged $\geq 40$ years and women aged $\geq 50$ years [20]. To unify and simplify the range of mandatory prophylactic examination, the authors of this study suggest conducting ECG, evaluating the glucose level and estimating the total cardiovascular risk by means of the POL-SCORE chart [12], for the first time in employees aged $\geq 40$ years and then every 5 years in patients without CVD or DM diagnosis, and without risk factors for CivDs. Each mandatory medical check-up should include the estimation of BMI and the measurement of waist circumference.

Testing FGL and the lipid profile in venous blood, preferably at least $9 \mathrm{~h}$ after the last meal, is difficult or even impossible if the prophylactic medical check-up of a worker is carried out in the afternoon or evening. However, nonfasting levels can be used for screening and general risk estimation $[20,44,45]$. What is more, in the Polish legislation, the employer is burdened with the total financial cost of employee examinations [10]. As previously stated, only $3 \%$ of the patients with $\mathrm{TC}$ in the normal range had LDL-C insignificantly over the upper limit. Therefore, the authors also suggest a random evaluation of glucose and TC levels even in the fingertip blood measured with a strip test during an occupational medicine visit. Diagnostic reliability of these assays is lower but sufficient for identifying people with significant metabolic impairments who need further diagnostics. A recently published Polish study revealed that $>90 \%$ of employees approve testing glucose and cholesterol profile in strip assays during prophylactic examinations and ECG, and almost $90 \%$ would accept the measurement of waist circumference [46].

As shown in the previous study [47], actions taken during mandatory prophylactic examinations of employees allow for an improved surveillance of hypertension in workers due to the fact that they are performed cyclically. The results of this study are supposed to provide directions for further preventive actions at the workplace. Reducing the incidence, sick leave and mortality because of selected CivDs among employees should be the notable effects leading to a reduced fluctuation of experienced professional staff and to increased labor effectiveness. 


\section{CONCLUSIONS}

The main strategy of CVD and diabetes prevention in occupationally active populations should focus on increasing physical activity in both leisure time and at the workplace as far as practicable. There is a need for implementing projects leading to occupational stress reduction and smoking cessation. Working men need to be encouraged and recruited to prevention programs. Primary prevention of CVDs and diabetes should focus on employees in their twenties and thirties, while secondary prophylaxis needs to be targeted at middle-age workers.

\section{REFERENCES}

1. Piepoli M, Hoes F, Agewall S, Albus C, Brotons C, Catapano A, et al. 2016 European Guidelines on cardiovascular prevention in clinical practice. The Sixth Task Force of the European Society of Cardiology and Other Societes on cardiovascular disease prevention in clinical practice. Eur Heart J. 2016;37:2315-81, https://doi.org/10.1093/eurheartj/ehw106.

2. Finucane M, Stevens G, Cowan M, Danaei G, Lin J, Paciorek C, et al. National, regional, and global trends in body mass index since 1980: systematic analysis of health examination surveys and epidemiological studies with 960 country-years and 9.1 million participants. Lancet. 2011;377:557-67, https:// doi.org/10.1016/S0140-6736(10)62037-5.

3. Danaei G, Finucane M, Lu Y, Singh G, Cowan M, Paciorek C, et al. National, regional, and global trends in fasting plasma glucose and diabetes prevalence since 1980: systematic analysis of health examination surveys and epidemiological studies with 370 country-years and 2.7 million participants. Lancet. 2011;378: 31-40, https://doi.org/10.1016/S0140-6736(11)60679-X.

4. Statistics Poland [Internet]. Warsaw: 2018 [cited 2018 May 20]. Statystyka zgonów i umieralności z powodu chorób układu krążenia. Available from: https://stat.gov.pl/obszary-tematyczne/ludnosc/ludnosc/statystyka-zgonow-i-umieralnosci-zpowodu-chorob-ukladu-krazenia,22,1.html. Polish.

5. Marmot M, Bosma H, Hemingway H, Brunner E, Stansfield S. Contribution of job control and other risk factors to social variations in coronary heart disease. Lancet. 1997;350:235340, https://doi.org/10.1016/s0140-6736(97)04244-x.

6. Rosengren A, Hawken S, Ounpuu S, Silwa K, Zubaid M, Almahmeed W, et al. Association of psychosocial risk factors with risk of acute myocardial infarction in 11,119 cases and 13,648 controls from 52 countries (the INTERHEART study): case-control study. Lancet. 2004;364:953-62, https:// doi.org/10.1016/S0140-6736(04)17019-0.

7. Chandola T, Brunner E, Marmot M. Chronic stress at work and the metabolic syndrome: prospective study. Br Med J. 2006;332:521-52, https://doi.org/10.1136/bmj.38693.435301.80.

8. Cooney M, Dudina A, Whincu P, Capewell S, Menotti A, Jousilahti P, et al. Revaluating the Rose approach: comparative benefits of the population and high risk preventive strategies. Eur J Cardiovasc Prev Rehabil. 2009;16:541-9, https:// doi.org/10.1097/HJR.0b013e32832b38a1.

9. Liu K, Daviglus M, Loria C, Colangelo L, Spring B, Moller A, et al. Healthy lifestyle through young adulthood and the presence of low cardiovascular disease risk profile in the middle age: the Coronary Artery Risk Development in (Young) Adults (CARDIA) study. Circulation. 2012;125:996-1004, https://doi.org/10.1161/CIRCULATIONAHA.111.060681.

10. [The Labour Code of 26 June 1974 with further changes. J Laws 1974, No. 24, item 141]. Polish.

11. Zdrojewski T, Jankowski P, Bandosz P, Bartuś S, Chwojnicki K, Drygas W, et al. [A new version of cardiovascular risk assessment system and risk charts calibrated for Polish population]. Kardiol Pol. 2015;73:958-61, https://doi.org/10.5603/ KP.2015.0182. Polish.

12. World Health Organization [Internet]. Geneva: The Organization; 2002 [cited 2018 May 5]. The world health report 2002 - Reducing Risks, Promoting Healthy Life. Available from: http://www.who.int/whr/2002/en/whr02_en. pdf?ua $=1$.

13. Lollgen H, Bockenhoff A, Knapp G. Physical activity and allcause mortality: an updated meta-analyses with different intensity categories. Int J Sports Med. 2009;30:213-24, https:// doi.org/10.1055/s-0028-1128150. 
14. Sattelmair J, Pertman J, Ding E, Kohl H, Haskell W, Lee I, et al. Dose response between physical activity risk of coronary heart disease: a meta-analysis. Circulation. 2011;124:789-95, https://doi.org/10.1161/CIRCULATIONAHA.110.010710.

15. Moore S, Patel A, Matthews C, Berrington de Gonzalez A, Park Y, Katki H, et al. Leisure time physical activity of moderate to vigorous intensity and mortality: a large pooled cohort analysis. PLoS Med. 2012;9:e1001335, https://doi. org/10.1371/journal.pmed.1001335.

16. Physical Activity Guidelines Advisory Committee, U.S. Department of Health and Human Services [Internet]. Washington: 2008 [cited 2018 Dec 20]. Physical Activity Guidelines Advisory Committee Report 2008. Available from: https://health.gov/paguidelines/2008/report/pdf/CommitteeReport.pdf.

17. Talbot L, Morrell C, Fleg J, Metter E. Changes in leisure time physical activity of all-cause mortality in men and women: the Baltimore Longitudinal Study of Ageing. Prev Med. 2007;45:169-76, https://doi.org/10.1016/j.ypmed.2007. 05.014 .

18. Lee I, Shiroma E, Lobelo F, Pusk P, Blair S, Katzmarzyk P, et al. Effect of physical inactivity on major non-communicable disease worldwide: an analysis of burden of disease and life expectancy. Lancet. 2012;380:219-29, https://doi. org/10.1016/S0140-6736(12)61031-9.

19. Catapano A, Graham G, De Backer G, Wiklund O, Chapman M, Drexel H, et al. 2016 ESC/EAS Guidelines for the management of dyslipidaemias of the European Society of Cardiology (ESC) and European Atherosclerosis Society (EAS). Eur Heart J. 2016;37(39):2999-3058, http://doi. org/10.1016/j.atherosclerosis.2016.08.018.

20. Referowska M, Leśniak W. [Postępowanie w dyslipidemiach. Podsumowanie wytycznych ESC 2016]. Med Prakt. 2017;1:12-41. Polish.

21. Cybulska B, Kłosiewicz-Latoszek L. [Komentarz. W: Referowska M, Leśniak W. Postępowanie w dyslipidemiach. Podsumowanie wytycznych European Society of Cardiology 2016]. Med Prakt. 2017;1:39-41. Polish.
22. European Respiratory Society [Internet]. Sheffield: 2013 [cited 2018 Sep 3]. European Lung White Book: Tobacco smoking. Available form: http://www.erswhitebook.org/chapters/ tobacco-smoking/.

23. Cahill K, Lancaster T. Workplace interventions for smoking cessation. Review. The Cochrane Collaboration. New Jersey: Wiley \& Sons; 2014.

24. Pisinger C, Dossing M. A systematic review of health effects of electronic cigarettes. Prev Med. 2014;69:248-60, https:// doi.org/10.1016/j.ypmed.2014.10.009.

25. Anthenelli R, Benowitz N, West R, St Aubin L, McRae T, Lawrence D, et al. Neuropsychiatric safety and efficacy of varenicline, bupropion, and nicotine patch in smokers with and without psychiatric disorders (EAGLES): a double-blind, randomized, placebo-controlled clinical trial. Lancet. 2016;387:250720, https://doi.org/10.1016/S0140-6736(16)30272-0.

26. [Order of 30 May 1996 of the Minister of Health Care and Social Welfare on carrying out of medical examinations of workers, to the extent of the preventive health care for workers, as well as on medical decisions issued to such ends provided for by the Labour Code with further changes. J Laws 1996, No. 69, item 332]. Polish.

27. Nofer Institute of Occupational Medicine and National Health Program [Internet]. Lodz: 2018 [cited 2018 Jul 6]. Available from: http://npz.net.pl/.

28. Polish Cardiac Society [Internet]. Warsaw: 2018 [cited 2018 Sep 1]. Co (dalej) po zawale? Available from: http://copozawale.pl. Polish.

29. Statistics Poland [Internet]. Warsaw: 2019 [cited 2019 April 17]. Labour Market in 2017. Available from: https:// stat.gov.pl/en/topics/labour-market/yearbook-of-labour/ labour-market-in-2017,1,1.html.

30. Morris J, Heady J, Raffle A, Roberts C, Parks J. Coronary heart-disease and physical activity of work. Lancet. 1953;265(6796):1111-20, https://doi.org/10.1016/s0140-6736 (53)91495-0.

31. Nagaya T, Kondo Y, Shibata T. Effects of sedentary work on physical fitness and serum cholesterol profile in 
middle-aged male workers. Int Arch Occup Environ Health. 2001;74(5):366-70, https://doi.org/10.1007/pl00007954.

32. Krantz D, Quigley J, O Callahan M. Mental stress a trigger of acute cardiac events: the role of laboratory study. Ital Hear J. 2001;12:895-9.

33. Mc Dougall S, Widdop R, Lawrence A. Central autonomic integration of psychological stressors. Focus on cardiovascular modulation. Auton Neurosci. 2005;123(1-2):1-11, https://doi.org/10.1016/j.autneu.2005.09.005.

34. Torres O, O'Dell L. Stress is a principal factor that promotes tobacco use in females. Prog Neuropsychopharmacol Biol Psychiatry. 2016;4(65):260-8, https://doi.org/10.1016/ j.pnpbp.2015.04.005.

35. Anthenelli R, Grandison L. Effects of stress on alcohol consumption. Alcohol Res. 2012;34(4):381-2.

36. Rosmond R, Bjorntop P. Occupational status, cortisol secretory pattern, and visceral obesity in middle-aged men. Obes Res. 2000;8:445-50, https://doi.org/10.1038/oby.2000.55.

37. Klesges R, Meyers A, Klesges L, LaVasque M. Smoking, body weight, and their effects on smoking behavior: a comprehensive review of the literature. Psychol Bul. 1989;106(2):204-30.

38. Akbartabartoori M, Lean ME, Hankey CR. Relationships between cigarette smoking, body size and body shape. Int J Obes. 2005;29(2):236-43, https://doi.org/10.1038/sj.ijo.0802827.

39. Yun JE, Kimm H, Choi YJ, Jee SH, Huh KB. Smoking Is Associated With Abdominal Obesity, Not Overall Obesity, in Men With Type 2 Diabetes. J Prev Med Public Health. 2012;45(5):316-22, https://doi.org/10.3961/jpmph.2012.45.5.316.

40. Tuovinen E, Saarni S, Männistö S, Borodulin K, Patja K, Kinnunen $\mathrm{T}$, et al. Smoking status and abdominal obesity among normal- and overweight/obese adults: Population-based FINRISK study. Prev Med Rep. 2016;4:324-30, https://doi. org/10.1016/j.pmedr.2016.07.003.
41. Gilbert D, Meliska C, Williams C, Jensen R. Subjective correlates of cigarette-smoking-induced elevations of peripheral beta-endorphin and cortisol. Psychopharmacology. 1992;106(2):275-81, https://doi.org/10.1007/bf02801984.

42. Bjorntorp P. Metabolic implications of body fat distribution. Diabetes Care. 1991;14(12):1132-43, https://doi.org/10.2337/ diacare.14.12.1132.

43. Conroy R, Pyorala K, Fitzgerald A, Sans S, Menotti A, De Backer $\mathrm{G}$, et al. Estimation of ten-year risk of fatal cardiovascular disease in Europe: the SCORE project. Eur H J. 2003;24:987-1003, https://doi.org/10.1016/s0195-668x (03)00114-3.

44. Clinical Diabetology. [2018 Guidelines on the management of diabetic patients. A position of Diabetes Poland]. Clin Diabetol. 2018;7(1):1-90, https://doi.org/10.5603/DK. 2018.0001. Polish.

45. Langsted A, Nordestgaard B. Nonfasting lipids, lipoproteins, and apolipoproteins in individuals with and without diabetes: 58434 individuals from the Copenhagen General Population Study. Clin Chem. 2011;57:482-9, https://doi. org/10.1373/clinchem.2010.157164.

46. Lipińska-Ojrzanowska A, Magnuska J, Świerczyńska-Machura D, Walusiak-Skorupa J, Marcinkiewicz A, Wiszniewska M, et al. [Workers' view on the preventive needs for civilization diseases' in prophylactic care taken on employees]. Med Pr. 2019;70(4):425-33, https://doi.org/10.13075/mp.5893.00 821. Polish.

47. Marcinkiewicz A, Plewka M, Hanke W, Kałużny P, Wiszniewska M, Lipińska-Ojrzanowska A, et al. [Is it possible to improve compliance in hypertension and reduce therapeutic inertia of physicians by mandatory periodic examinations of workers?]. Kardiol Pol. 2018;76(3):554-9, https://doi. org/10.5603/KP.a2017.0250. Polish.

This work is available in Open Access model and licensed under a Creative Commons Attribution-NonCommercial 3.0 Poland License - http://creativecommons.org/ licenses/by-nc/3.0/pl/deed.en. 